\title{
EVALUASI MATA KULIAH PENDIDIKAN KARAKTER PRODI PGMI FTK UIN ANTASARI BANJARMASIN
}

\author{
Waluyo Satrio Adji, Rahmad, Bima Ramadhan \\ Program Studi Pendidikan Guru Madrasah Ibtidaiyah \\ Universitas Islam Negeri Antasari \\ waluyo.satrio.adji@uin-antasari.ac.id
}

\begin{abstract}
The objectives of this research are (1) to know the factors that influence the decision of 2014 PGMI majoring students in choosing elective courses, (2) to know the dominant factors influencing the 2014 PGMI majoring students' choices in choosing elective courses. This study uses a qualitative approach by giving questionnaires that must be filled by students who take character education courses. Respondents of the research were 2014 Antasari UMI PGK FTK UIN students, while the sample in the pilot phase was Antasari PGMI FTK UIN class 2015. The results of the study describe (1) the factors that influence the decision of 2014 PGMI majoring students in choosing elective courses in the Antasari Banjarmasin PGMI major, including parents, peers, gender personality (interests and motivation), college image, job prospects. (2) the dominant factor influencing the 2014 student's PGMI majoring decision is the gender factor and job prospects. Percentage of 43 students or 57.3\% chose that character education courses for all sexes. The percentage of job prospects is 42 students or $56 \%$ choose to agree that character education is beneficial for future employment.
\end{abstract}

Keywords: evaluation; course; character education; PGMI

\begin{abstract}
ABSTRAK
Tujuan dalan penelitian ini adalah (1) mengetahui faktor-faktor yang mempengaruhi keputusan mahasiswa jurusan PGMI angkatan 2014 dalam memilih mata kuliah pilihan, (2) mengetahui faktor yang dominan mempengaruhi keputusan mahasiswa jurusan PGMI angkatan 2014 dalammemilih mata kuliah pilihan jurusan. Penenlitian ini menggunakan pendekatan kualitatif dengan memberi kuesioner yang harus diisi mahasiswa yang mengambil mata kuliah pendidikan karakter. Responden penelitian adalah mahasiswa PGMI FTK UIN Antasari tahun angkatan 2014, sedangkan yang menjadi sample dalam tahapan uji coba adalah mahasiswa PGMI FTK UIN Antasari angkatan 2015. Hasil penelitian memaparkan (1) faktor-faktor yang mempengaruhi keputusan mahasiswa jurusan PGMI angkatan 2014 dalam memilih mata kuliah pilihan jurusan PGMI UIN Antasari Banjarmasin, antara lain orang tua, teman sebaya, genderm kepribadian (minat dan motivasi), citra perguruan tinggi,prospek pekerjaan. (2) faktor yang dominan mempengaruhi keputusan mahasiswa jurusan PGMI angkatan 2014 adalah faktor gender dan prospek pekerjaan. Presentase 43 mahasiswa atau sebesar 57,3\% memilih bahwa mata kuliah pendidikan karakter untuk semua jenis kelamin. Presentase prospek pekerjaan sebesar 42 mahasiswa atau 56\% memilih setuju bahwa pendidikan karakter bermanfaat untuki pekerjaan di masa depan.
\end{abstract}

Kata Kunci : evaluasi; mata kuliah; pendidikan karakter; PGMI 


\section{PENDAHULUAN}

Pendidikan adalah upaya terencana dalam mengatur lingkungan dan proses pembelajaran dengan tujuan agar siswa secara aktif mengoptimalkan berbagai potensi yang dimilikinya meliputi religius, emosi, kontrol diri, karakter, spiritual, kecekatan, kepribadian, dan keterampilan. Kemudian disebutkan pula bahwa pendidikan nasional adalah pendidikan berlandaskan Pancasila dan UUD Negara Republik Indonesia Tahun 1945 yang bermula pada nilai-nilai hal ini tercantum dalam Undang-undang no 20 tentang system pendidikan nasional pada ketentuan umum pasal 1.

Program Penguatan Pendidikan Karakter adalah salah satu perwujudan dari konsep Kementerian Pendidikan dan Kebudayaan (Kemendikbud). Pengertian Karakter dari dokumen rencana aksi nasional terbitan kementerian pendidikan adalah kualitas yang menjadi penciri individu dan grup. Karakter pada artian ini dapat berbentuk terpuji dan tercela. Karakter yang ingin dijewantahkan oleh bangsa Indonesia adalah karakter terpuji yang sesuai dengan jawaban dari tantangan dari perubahan dinamis masyarakat. Internalisasi nilai-nilai karakter bangsa melalui pendidikan membutuhkan pengembangan yang terintegrasi dengan bagian-bagian perkembangan siswa secara seimbang antara pemikiran dan perbuatan.

Pengintegrasian Penguatan Pendidikan Karakter disingkat PPK dalam lingkungan pendidikan merupakan suatu keharusan dan dapat menjadi salah satu tujuan dari pendidikan. Pembangunan karakter (character buildings) pada perguruan tinggi khususnya Perguruan Tinggi Islam menjadi suatu keharusan pula. Lingkup terkecil dari sebuah perguruan tinggi atau program studi dalam hal ini adalah PGMI. Pendidikan karakter menjadi sebuah keharusan. PGMI melahirkan tenaga pendidik yang dalam visinya adalah terdepan dalam melahirkan sarjana pendidikan guru madrasah ibtidaiyah yang unggul dan berakhlak mulia.

Salah satu mata kuliah pilihan yang terdapat di jurusan Pendidikan Guru Madrasah Ibtidaiyah UIN Antasari adalah pendidikan karakter, selain pendidikan Inklusi dan pendidikan multimedia. Pendidikan karakter adalah mata kuliah pilihan yang baru disajikan dalam mata kuliah pilihan di jurusan PGMI UIN Antasari tahun 2014. Tetapi dalam perkembangannya mata kuliah character education cenderung jumlah pilihan mahasiswa yang banyak dipilih dibandingkan mata kuliah pilihan lain (pendidikan inklusi dan multimedia pembelajaran) dilihat dari jumlah pengambil mata kuliah pilihan tersebut (hasil wawancara dengan ketua jurusan PGMI FTK UIN Antasari). 
Beberapa permasalahan diatas membuat tim penulis merasa perlu untuk mengadakan penelitian tentang fenomena tersebut. Serta perlu mengungkap latar belakang mahasiwa yang menjadikan mata kuliah pendidikan karakter sebagai pilihannya.

\section{Evaluasi Pembelajaran}

Secara bahasa Inggris evaluasi berarti evaluation, pada bahasa Indonesia berarti penilaian dan bahasa Arab at-Taqdir. Secara Istilah menurut Komite Studi Nasional dari UCLA (Stark \& Thomas, 1994:12) tentang evaluasi mendefinisikan evaluasi sebagai kegiatan pengelolahan informasi sehingga digunakan sebagai dasar pengambilan keputusan juga bermanfaat untuk penyusunan program ke depannya (Eko, 2011:4).

Pembelajaran merupakan interaksi antara guru dan siswa untuk memanfaatkan berbagai potensi yang ada pada siswa. Definisi tersebut menandakan bahwa terjadi proses saling bekerja sama, yang di dalamnya tidak hanya menitikberatkan pada kegiatan guru saja, akan tetapi guru dan siswa berupaya mencapai tujuan pembelajaran. Perubahan perilaku siswa dari aspek kognitif, afektif, dan psikomotorik adalah tujuan dari pembelajaran.(Wina, 2008:8)

Beberapa definisi di atas dapat ditarik kesimpulan bahwa evaluasi pembelajaran adalah proses mengelolah informasi dari hasil interaksi antara guru dan siswa dalam proses belajar guna mengetahui kekurangan yang selanjutnya dilakukan perubahan ke arah perbaikan, hasil dari pengelolahan informasi dimanfaatkan sebagai pertimbangan bahan pengambil keputusan dalam penyusunan program selanjutnya.

\section{Fungsi Evaluasi Pembelajaran}

Chabib Thohha membagi fungsi evaluasi pembelajaran dilihat kepentingan sekolah atau universitas adalah sebagai berikut:
a. Mengukur mutu hasil pendidikan.
b. Memahami kekurangan dan kelebihanpada lembaga pendidikan.
c. Pertimbangan untuk membuat keputusan.
d. Mengadakan perubahan kurikulum. (Thoha, 1996: 11)

\section{Pengertian Karakter}

Karakter menurut Zubaedi mendefinisikan "karakter adalah pembawaan, hati, jiwa, kepribadian, personalitas, perilaku, sifat, budi pekerti, emosional, tabiat, dan watak. (Zubaedi, 2011:6) Sedangkan menurut Rusdianto "Karakter tidak diwariskan, tetapi sesuatu yang dibangun secara berlanjut langkah demi langkah melalui pikiran dan tindakan. Karakter 
dimaknai sebagai mindset dan berperilaku dijadikan penciri tiap manusia untuk hidup dan berhubungan, pada lingkup keluarga, masyarakat, bangsa, dan Negara”. (Rusdianto, 2012: 38)

Karakter merupakan perubahan positif meliputi aspek intelektual, emosional, sosial, etika, dan perilaku. Bila siswa bertindak sesuai dengan potensi dan kesadarannya disebut pribadi yang berkarakter baik dengan indikatornya mereka berupaya melakukan hal-hal yang terbaik terhadap Tuhan, pribadi, masyarakat, lingkungan, bangsa, dan dunia, dengan memaksimalkan potensi (kognitif) diikuti dengan kesadaran, emosi dan motivasi (Aunillah, $: 21)$.

Dasar hukum dalam pelakasanaan pendidikan karakter termaktub dalam UndangUndang Nomor 20 Tahun 2003 Sisdiknas pada pasal 1 yang secara garis besar menyatakan salah satunya fungsi Pendidikan Nasional adalah mengembangkan kemampuan dan membentuk watak dengan tujuan menjadi warga negara yang paripurna. (UUD Sisdiknas) Landasan religi yang digunakan dalam uraian ini adalah landasan atau dasar-dasar yang bersumber dari Al-Qur'an. Pendidikan karakter dalam Al-Qur'an surat An-Nahl ayat 125. (Jalalludin, 1992: 103).

\section{Faktor-faktor yang Mempengaruhi Perkembangan Karir}

Dalam menentukan pilihan setiap orang pasti dipengaruhi oleh berbagai faktor, terlebih lagi jika pilihan tersebut berkaitan dengan masa depan, salah satunya menentukan jurusan. Menentukan jurusan yang akan dipilih pada tingkat perguruan tinggi pada dasarnya termasuk pada perencanaan karir. Hal ini tentu saja menjadi penting, terlebih bagi calon mahasiswa yang hendak atau edang menempuh pendidikan di perguruan tinggi, khususnya di UIN Syarif Hidayatullah Jakarta.

Kelompok mahasiswa termasuk pada kelmpok remaha akhir-dewasa awal. Pada kelompok ini, ada beberapa tugas dalam tahap perkembangannya. Salah satunya menurut Duvall, yakni memilih dan mempersiapkan pekerjaan dan keterbegantungan ekonomi. Selanjutnya guna mempersiapkan pekerjaan sebagian orang memilih untuk menempuh endidikan hingga perguruan tinggi. Namun dalam proses memilih dan memutuskan seringkali seseorang dilanda kebingungan. Hal ini tidak dapat dipungkiri karena jurusan yang dipilih akan menjadi gerbang utama dalam pilihan karir di masa depan. Ada berbagai hal yang memepengaruhi seseorang dalam pengambilan keputusan memilih jurusan yakni salah satunya menurut Berk 
bahwa pengambilan keputusan dalam menentukan karir seseorang dipengaruhi oleh beberapa faktor, di antaranya: orang tua, teman, gender, karakteristik pribadi.

a. Orang tua

Orang tua adalah ibu dan ayah yang merupakan figur yang dapat ditiru oleh anak-anaknya (Mardiya, 2000).

b. Kelompok Sebaya (peer-group)

Tidak bisa dikesampingkan kenyataannya bahwa lingkungan pergaulan dalam kelompok cukup memberi pengaruh pada pribadi seorang dalam memilih program studi di SLTA atau mungkin di perguruan tinggi. Hal ini terkait dengan kebutuhan psikologi remaja yang ingin keberadaan mereka diakui dalam sebuah kelompok bermain atau teman sebaya. Apalagi bagi individu yang telah mempunyai teman dekat atau sahabat, dimungkinkan terpengaruh untuk memasuki program studi atau jurusan yang sama atau mungkin mengambil lembaga pendidikan yang sama.

Lingkungan metupakan faktor yang mempengaruhi seseorang dalam menjalani pilihan hidup tidak hanya di dalam dirinya saja, ketika pilihan internal mahasiswa menginginkan menjadi guru dan lingkungan baik keluarga, teman sebaya, sekolah dan masyarakat mendukung maka timbul kepercayaan diri mahasiswa tersebut dalam menempuh pendidikan karena merasa bahwa pilihannya bukanlah pilihan yang salah dengan itu menjadi dasar baginya untuk berprestasi lebih baik lagi untuk menunjukkan bahwa apa yang dia yakini serta apa yang telah lingkungan dukung untuknya adalah sebuah pilihan tepat.

c. Gender (Jenis Kelamin)

Muhtar dalam Froom (2002:56) mendefiniskan gender sebagai "jenis kelamin sosial yang menentukan peran sosial berlandaskan jenis kelamin”. Definisi gender bisa dijelaskan secara sederhana yaitu merupakan perbedaan antara laki-laki dan perempuan namun memiliki hak yang sama.

d. Karakteristik Kepribadian Individu

Kepribadian menurut berasal dari kata personality, yang berarti kepribadian, tokoh, watak yang kuat. Kepribadian diartikan sebagai penciri individual hasil kesatuan dari sifat, tempramen, kompetensi umum dan bakat yang dalam perkembangannya diintervensi oleh hubungan individu dengan lingkungannya. Pada aspek kepribadian individu aspek yang akan dibahas adalah minat dan motivasi dalam diri seseorang kaitannya dengan keputusan mahasiswa dalam memilih mata kuliah pilihan. 
1) Minat

Kecenderungan yang konsisten untuk mengingat dan mengamati beberapa kegiatan disebut minat. Kegiatan yang diminati seseorang, diamati secara berlanjut diiringi dengan perasaan senang disebut juga minat.

2) Motivasi

Oemar Hamalik (2004:173) mendefiniskan motivasi sebagai proses membangkitkan, mempertahankan, dan mengontrol minat-minat. Pengertian motivasi disimpulkan secara sederhana bahwa motivasi adalah suatu dorongan untuk melakukan tindakan, pemberi arah dalam tingkah lakunya.

e. Citra Perguruan Tinggi

Guru Besar Ekonomi Universitas Indonesia Rhenald Kasali mendefinisikan bahwa citra adalah kesan yang diakibatkan oleh pemahaman atas informasi pada kenyataan. Berdasarkan definisi citra dilihat dari pandangan para ahli dapat ditarik benang merah bahwa citra adalah kesan seseotang terhadap suatu objek yang diperoleh memalui informasi berdasarkan dari tingkat pengetahuan serta pemahaman kepada objek tersebut. Dalam penelitian ini, citra menjadi salah satu landasan yang menarik bagi mahasiswa dalam memilih mata kuliah pendidikan karakter dalam mata kuliah pilihan yang disediakan jurusan PGMI UIN Antasari

f. Prospek Pekerjaan Masa Depan

Faktor yang satu ini tidak dapat dihindari karena tingkat pendidikan seseorang akan membantu dalam perluasan kesempatan bekerja dan mendapat gaji layak sebagai ebuah apresiasi atas kemampuan yang dimiliki setelah mendapat ijasah. Meskipun tujuan utama dalam menempuh pendidikan adalah memperoleh ilmu sesrta mengambangkan potensi namun setelah seseorang menyelesaikan pendidikannya orientasi tentu berubah, tidak lagi hanya dapat memuaskan hasrat mengembangkan ilmu namun juga bagaimana ilmu yang dipelajari dapat menunjang kehidupan di lapangan kerja secara profesional guna mencukupi kehidupan melalui profesi yang ditekuni

\section{METODE PENELITIAN}

Penelitian ini menggunakan pendekatan kualitatif dengan memberi kuesioner kepada mahasiswa yang mengambil mata kuliah pendidikan karakter. Responden penelitian ini adalah mahasiswa PGMI FTK UIN Antasari tahun angkatan 2014, sedangkan yang menjadi 
responden dalam tahapan uji coba adalah mahasiswa PGMI FTK UIN Antasari tahun angkatan 2015.

Subjek dalam penelitian ini adalah mahasiswa PGMI yang memilih mata kuliah pilihan jurusan. Adapun yang menjadi objek dalam penelitian ini adalah faktor-faktor yang mempengaruhi keputusan mahasiswa dalam pemilihan mata kuliah pilihan PGMI FTK UIN Antasari.

Populasi dalam penelitian ini meliputi seluruh mahasiswa Jurusan PGMI angkatan 2014 yang mengambil mata kuliah pilihan pendidikan karakter. Yang berjumlah 175 mahasiswa. Penentuan jumlah sampel mengikuti rumus Isaac Michel sebagai berikut.

$$
n=\frac{(175)(1,96)^{2}(0,25)^{2}}{(175)(0,05)^{2}+(1,96)^{2}(0,25)^{2}}=62
$$

Berdasarkan rumus diatas maka kami menentapkan bahwa sampel yang diteliti berjumlah 62 mahasiswa PGMI menurut keterwakilannya. Teknik pengumpulan data dalam penelitiaan ini, peneliti menggunakan 3 teknik pengumpulan data, yaitu: Kuesioner, Wawancara, dan Observasi.

\section{HASIL DAN PEMBAHASAN}

\section{Faktor Orang Tua}

Mata kuliah pendidikan karakter dipilih mahasiswa berdasarkan pertimbangan orang tua dapat dideskripsikan dengan hasil bahwa 12 orang atau 16\% sangat setuju , 19 orang atau 25,3\% menyatakan setuju bahwa orang tua sebagai alasan pemilihan mata kuliah, 28 orang atau $37.3 \%$ menyatakan kurang setuju dengan asumsi tersebut dan sisanya sebanyak 16 atau 21,3\% menyatakan sangat tidak setuju. Hasil selengkapnya pada diagram berikut. 


\section{Faktor Orang Tua}

\section{Orang tua menjadi salah satu alasan utama dalam memilihkan mata kuliah pendidikan karakter \\ 75 tanggapan}

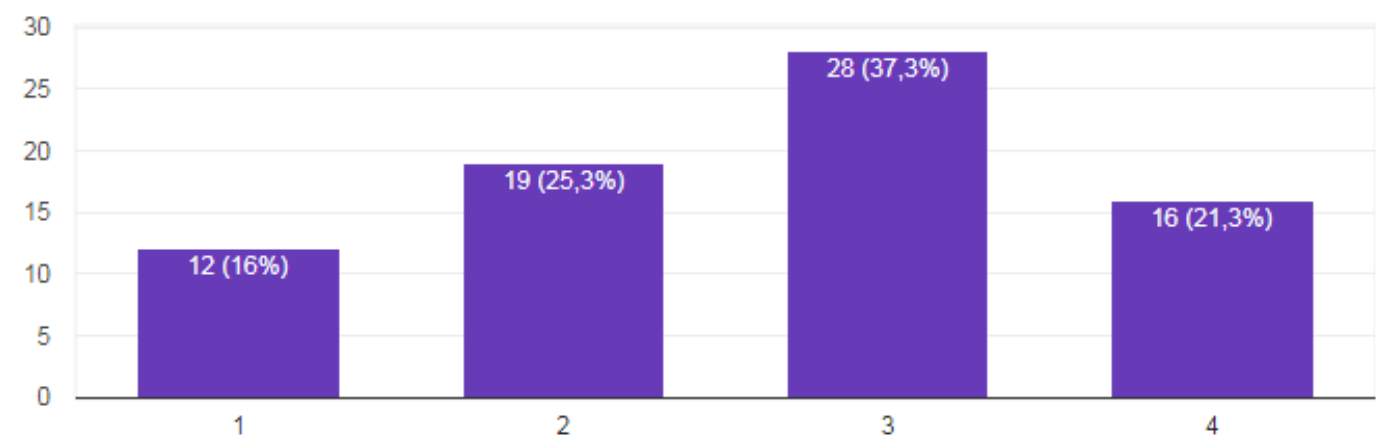

Gambar 1. Persentase Orang Tua Menjadi Alasan Utama Memilij Mata Kuliah Pendidikan Karakter Pernyataan selanjutnya bahwa pemilihan mata kuliah pilihan atas dasar kecocokan menurut orang tua, dijawab oleh mahasiswa dengan pernyataan sangat tidak setuju sebanyak 12 orang atau $16 \%$ sangat tidak setuju dengan pernyataan tersebut, kemudian sebanyak 31 orang atau 41,3\% menyatakan tidak setuju, kemuidan 26 mahasiswa atau 32,7 menyatakan setuju dan 6 orang atau $8 \%$ menyatakan sangat setuju. Selengkapnya pada diagramberikut.

Menurut orang tua saya, saya cocok mengambil mata kuliah pendidikan karakter

75 tanggapan

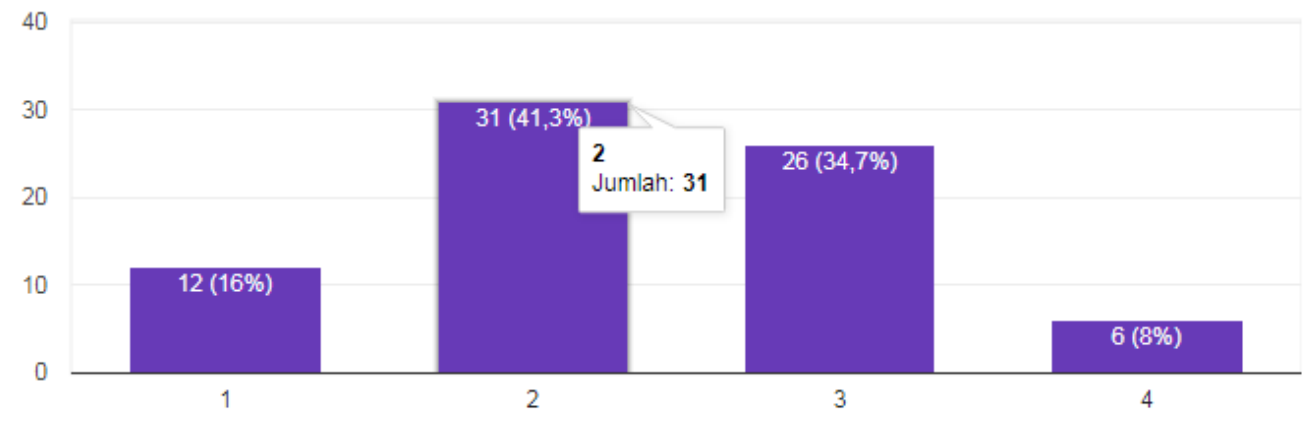

Gambar 2. Persentase Menurut Orang Tua dalam Mengambil Mata Kuliah 
Motivasi dari teman sebaya dalam memilih mata kuliah pendidikan karakter dapat dijabarkan sebagai berikut, 10 orang mahasiswa atau $13,3 \%$ sangat setuju dengan pernyataan tersebut, 17 mahasiswa atau $22,7 \%$ setuju dengan pernyataan tersebut, 30 mahasiswa atau $40 \%$ tidak setuju dengan pendapat tersebut dan 18 mahasiswa atau $24 \%$ sangat tidak setuju dengan pernyataan tersebut

\section{Teman Sebaya}

\section{Saya lebih mengikuti teman-teman dalam memilih mata kuliah}

75 tanggapan

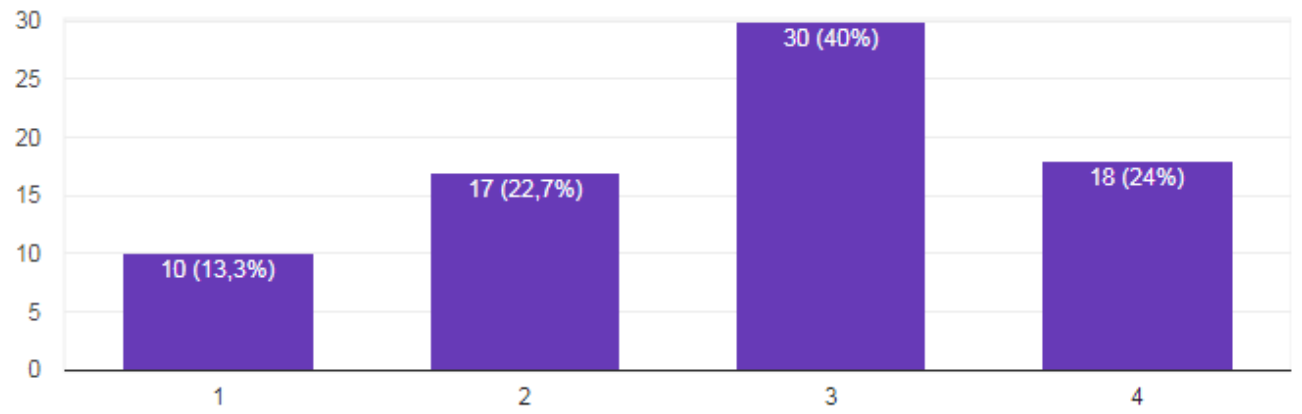

\section{Gambar 3. Persentase Mengikuti Teman Sebaya}

Banyaknya teman yang mengambil mata kuliah pilihan menjadi salah satu pertimbangan dalam memutuskan memilih mata kuliah yang sama lebih lanjut bisa diterangkan sebagai berikut, ada 11 mahasiswa memilih sangat setuju dengan presentase sebesar 14,7\%, 34 mahasiswa atau sekitar 45,3\% memilih setuju, 18 mahasiswa atau sekitar $24 \%$ memilih tidak setuju, dan yang terakhir 12 mahasiswa memilih sangat tidak setuju atau sebesar $16 \%$. pada diagram berikut. 


\section{Banyak teman yang mengambil mata kuliah pendidikan karakter menjadi salah satu pertimbangan saya dalam memilih mata kuliah pendidikan karakter \\ 75 tanggapan}

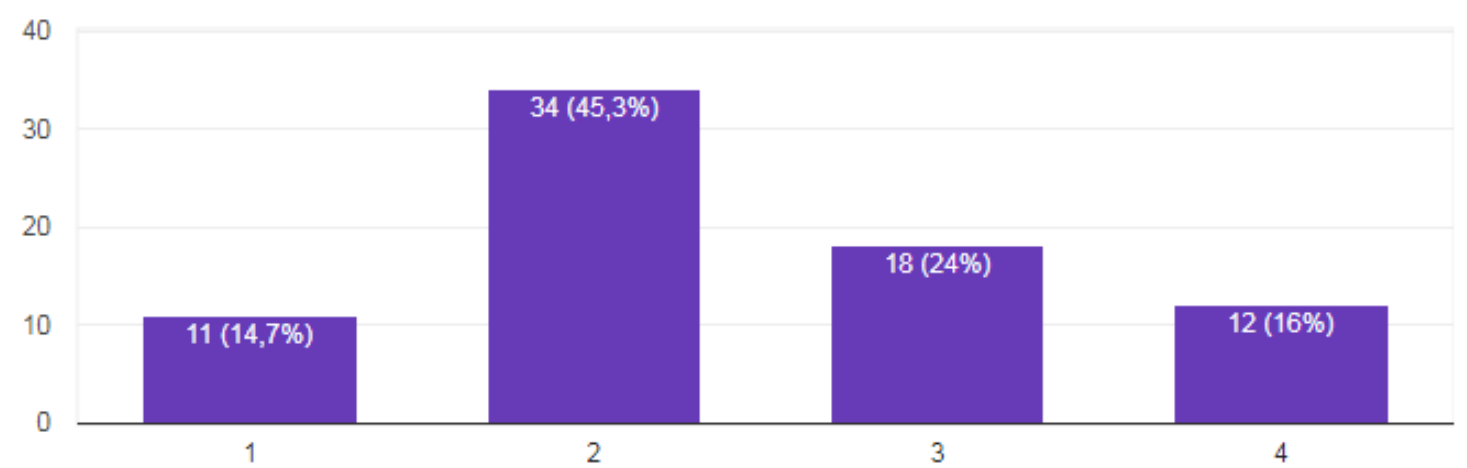

Gambar 4. Persentase Pertimbangan karena Teman Sebaya

Faktor gender atau jenis kelamin adalah yang melatar belakangi mahasiswa memilih mata kuliah pendidikan karakter, lebih lanjut bisa dijelaskan sebagai berikut, untuk butir pernyataan tentang kecocokan mata kuliah pendidikan karakter dengan salah satu jenis kelamin, didapati sebagai berikut, sebanyak 7 mahasiswa atau sekitar 9,3\% memilih sangat setuju, 10 mahasiswa memilih setuju atau sebesar 13,3\% memilih tidak setuju, sedangkan yang paling dominan 43 mahasiswa atau sebesar 57,3\% memilih sangat tidak setuju. Selengkapnya pada diagram berikut

\section{Gender}

mata kuliah pendidikan karakter hanya cocok bagi salah satu jenis kelamin (laki-laki atau perempuan)

75 tanggapan

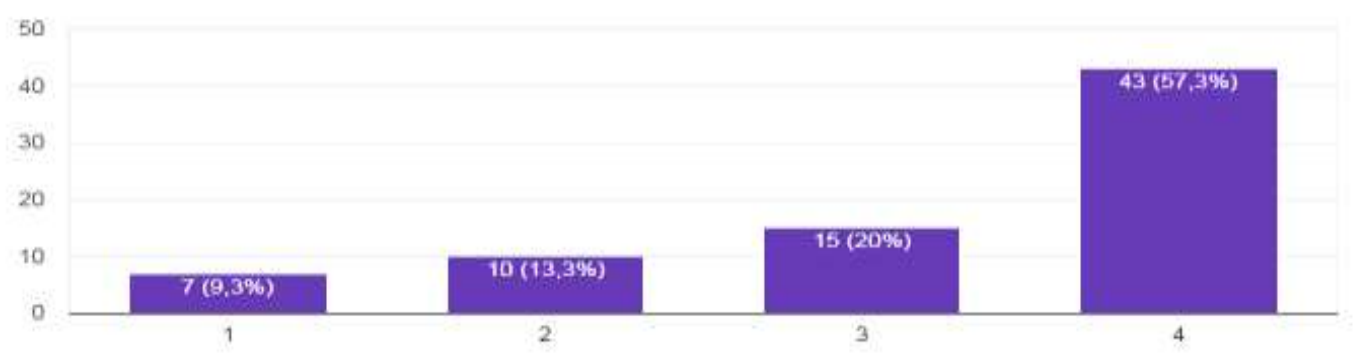

Gambar 5. Persentase Mata Kuliah Pendidikan Karakter karena Jenis Kelamin 
Pendominasian pemilihan mata kuliah pendidikan karakter baik laki-laki atau perempuan bisa dijelaskan sebagai berikut, sebesar 5 mahasiswa atau 6,7\% memilih sangat setuju, 15 mahasiswa atau $20 \%$ memilih setuju, 26 mahasiswa atau 34,7\% memilih tidak setuju, dan yang paling dominan sebanyak 29 mahasiswa atau 38,7\% memilih sangat tidak setuju Selengkapnya pada diagram berikut.

\section{mata kuliah pendidikan karakter didominasi oleh salah satu jenis kelamin (laki-laki atau perempuan) \\ 75 tanggapan}

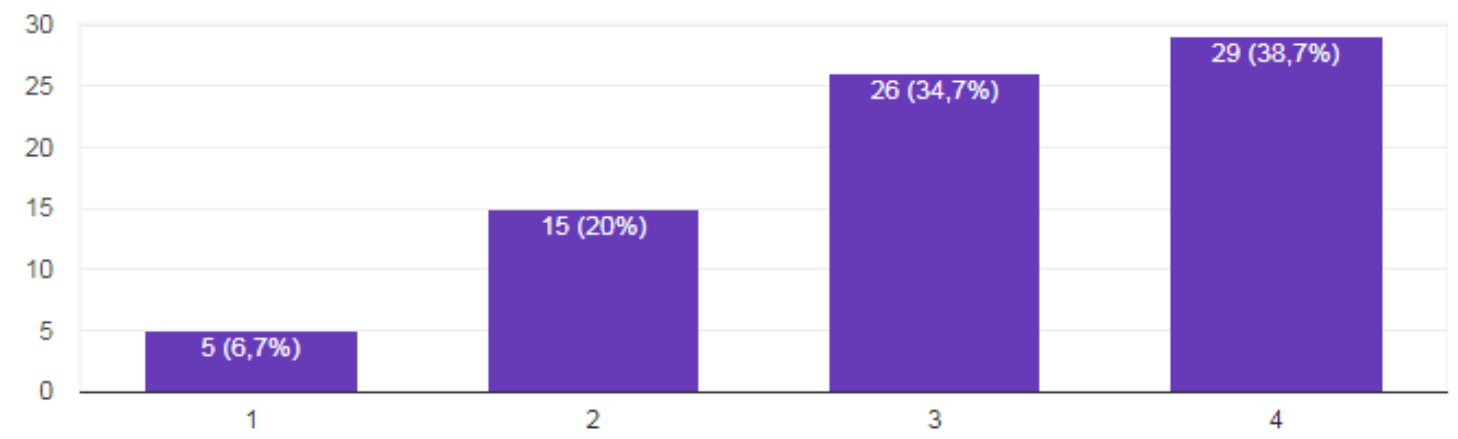

Gambar 6. Persentase Mata Kuliah Pendidikan Karakter karena Jenis Kelamin

Pernyataan selanjutnya adalah pemilihan mata kuliah dikarenakan faktor dosen dapat digambarkan sebagai berikut; 14 orang mahasiswa atau 18,7\% sangat setuju dengan pernyataan tersebut, 30 orang mahasiswa atau $40 \%$ setuju dengan pernyataan tersebut. Selanjutnya 22 orang mahasiswa atau 29,3\% tidak setuju dengan pernyataan tersebut dan 9 orang mahasiswa atau $12 \%$ menyatakan sangat tidak setuju. Selengkapnya pada diagram. 
Dosen mata kuliah pendidikan karakter merupakan mata kuliah yang memenuhi minat sebagian laki-laki atau perempuan

75 tanggapan

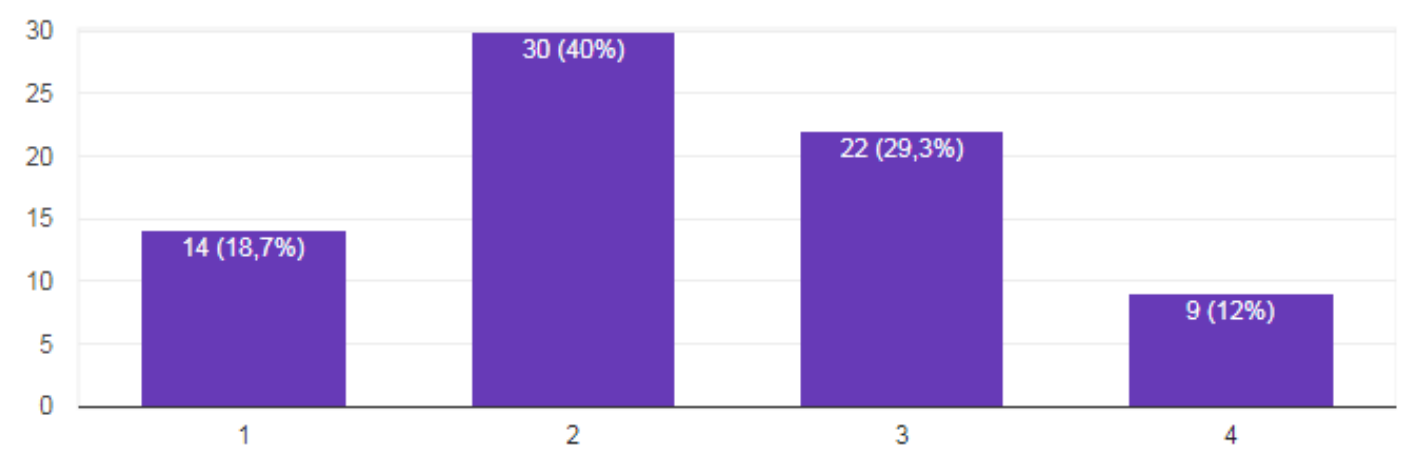

\section{Gambar 7. Persentase Dosen Mata Kuliah Pendidikan Karakter}

Angket pemilihan mata kuliah pilihan didasarkan oleh keinginan pribadi dapat ditelaah melalui pernyataan berikut. Pernyataannya adalah mahasiswa menyukai hal yang berkaitan dengan mata kuliah tersebut atau pendidikan karakter. Disebutkan bahwa 6 orang mahasiswa atau $8 \%$ sangat tidak setuju dengan pernyataan tersebut, kemudian 8 orang mahasiswa atau $10,7 \%$ tidak setuju. 30 orang mahasiswa atau $40 \%$ menyatakan dia setuju memilih mata kuliah pilihan dikarenakan kesukaannya dengan mata kuliah tersebut. Sebanyak 31 orang lainnya menyatakan sangat setuju. Selengkapnya pada diagram berikut.

\section{Kepribadian}

Saya menyukai hal-hal yang berkaitan dengan mata kuliah pendidikan karakter

75 tanggapan

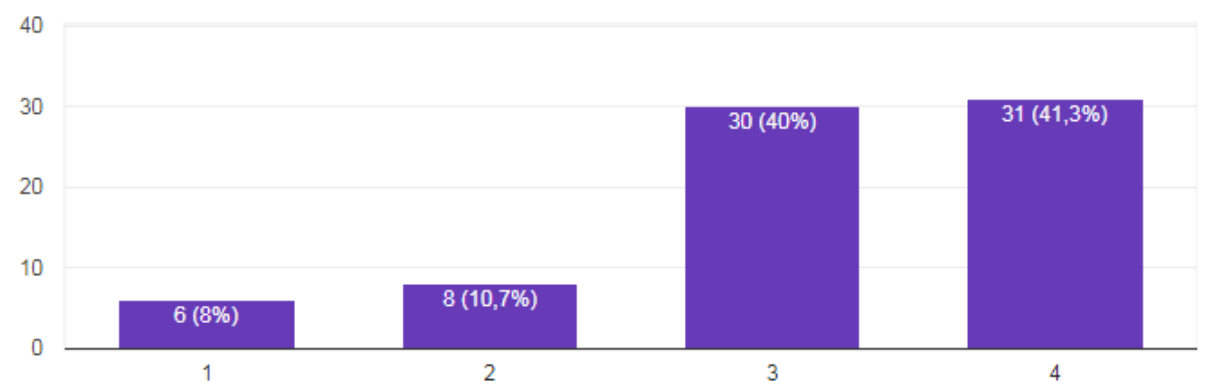

Gambar 8. Persentase Suka Mata Kuliah Pendidikan Karakter 
Selanjutnya dikarenakan mata kuliah pilihan merupakan mata kuliah yang dapat membuat mahasiswa berinteraksi dengan mahasiswa lainnya, maka kami juga memasukkan angket tentang kepribadiannya. Dalam angket disebutkan penyataan bahwa saya mudah bergaul dengan siapa saja. Responden atau mahasiswa menjawab dengan pernyataan sangat tidak setuju sebanyak 3 orang atau 4\%, 17 orang atau 22,7\% menjawab tidak setuju, 37 orang atau $49,3 \%$ menjawab setuju serta 18 orang atau $24 \%$ menjawab sangat setuju. Selengkapnya pada diagram berikut.

\section{Saya mudah bergaul dengan siapa saja}

\section{5 tanggapar}

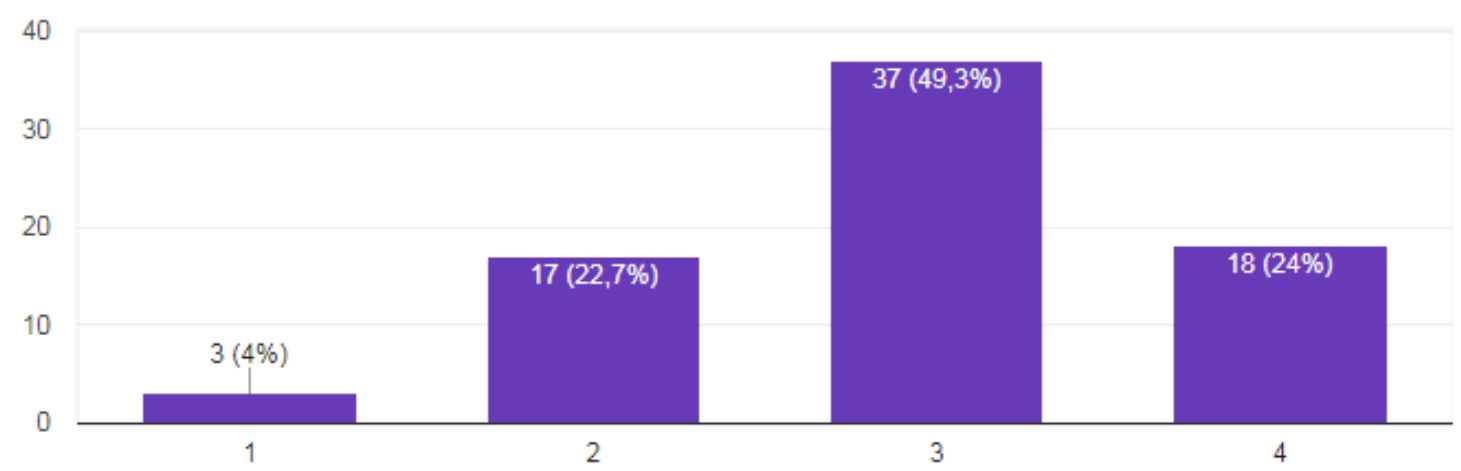

\section{Gambar 9. Persentase Mahasiswa Mudah Bergaul dengan Siapa Saja}

Pada pemilihan mata kuliah pilihan mensyaratkan setiap mahasiswa harus mempunyai nilai yang cukup sebelum memilih mata kuliah pendidikan karakter, dari hal itu dibuat butir angket pernyataan tentang nilai mahasiswa yang cukup dalam mengambil mata kuliah pendidikan karakter, lebih jelasnya hasilnya dijelaskan sebagai berikut 6 mahasiswa atau $8 \%$ memilih sangat tidak setuju, 9 mahasiswa atau 12\% memilih tidak setuju, paling dominan sekitar 39 mahasiswa atau 52\% memilih setuju, dan 21 mahasiswa atau $28 \%$ memilih sangat setuju. 


\section{Nilai saya sangat cukup untuk memilih mata kuliah pendidikan karakter} 75 tanggapan

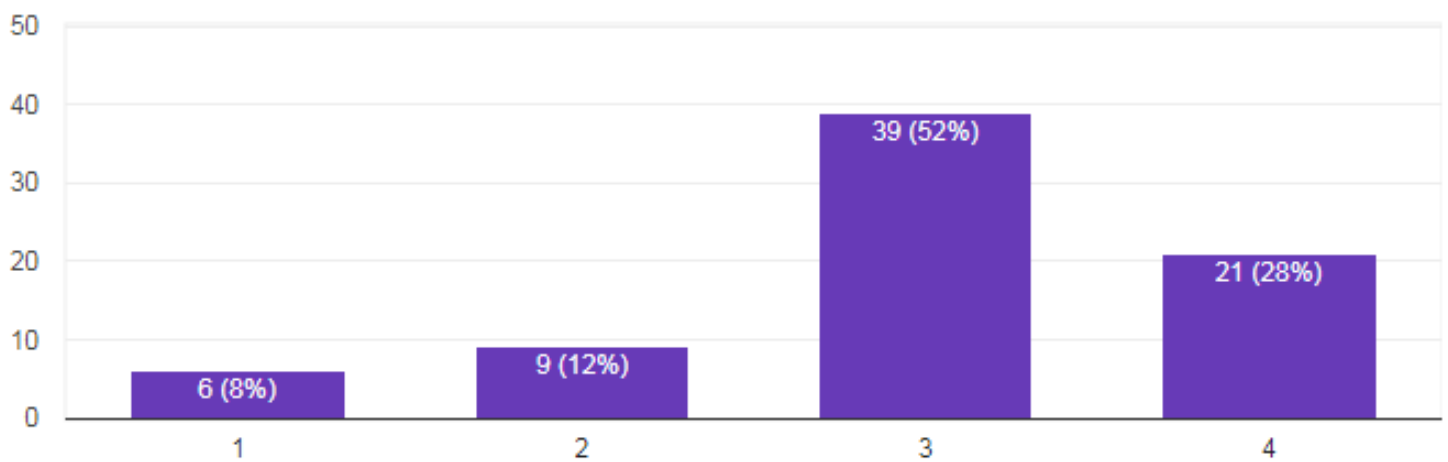

Gambar 10. Persentase Hubungan Nilai dan Mata Kuliah Pendidikan Karakter

Skala prioritas merupakan rencana dalam mempertimbangkan pemilihan mata kuliah pilihan, dalam angket ini terdapat pernyataan mata kuliah pendidikan karakter merupakan pilihan pertama, lebih jelasnya bisa dijabarkan sebagai berikut 7 mahasiswa atau 9,3\% memilih sangat tidak setuju, 15 mahasiswa atau $20 \%$ memilih tidak setuju, paling dominan 39 mahasiswa memilih setuju atau 39\%, sisanya 14 mahasiswa memilih sangat setuju atau $18,7 \%$.

mata kuliah pendidikan karakter adalah pilihan pertama saya dari mata kuliah pilihan yang ada

\section{5 tanggapan}

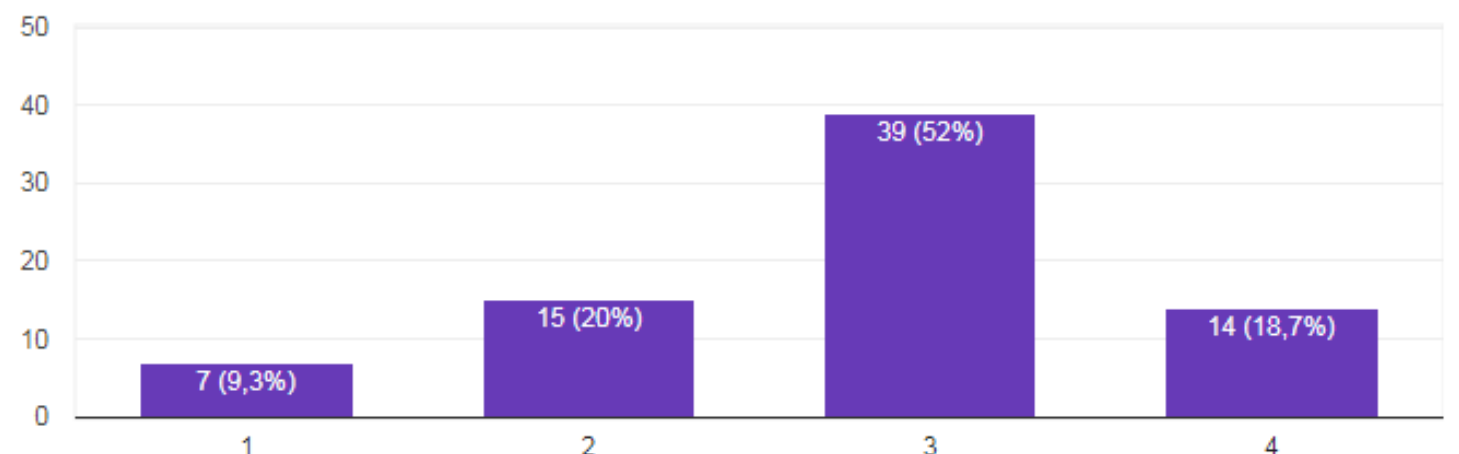

Gambar 11. Persentase Mata Kuliah Pendidikan Karakter adalah Pilihan Pertama 
Kepopuleran dari mata kuliah pendidikan karakter menjadi pertimbangan dalam memutuskan pemilihan mata kuliah, dalam angket terdapat butir pernyataan pendidikan karakter adalah mata kuliah cukup popular, lebih jelasnya 15 mahasiswa atau $20 \%$ memilih sangat setuju, 26 mahasiswa atau 34,7\% memilih setuju, hasil yang sama didapat 26 mahasiswa atau 34,7\% memilih tidak setuju, dan 8 mahasiswa atau 10,7\% memilih sangat tidak setuju. Lebih lanjut pada diagram berikut.

\section{Menurut saya mata kuliah pendidikan karakter adalah mata kuliah yang cukup populer \\ 75 tanggapan}

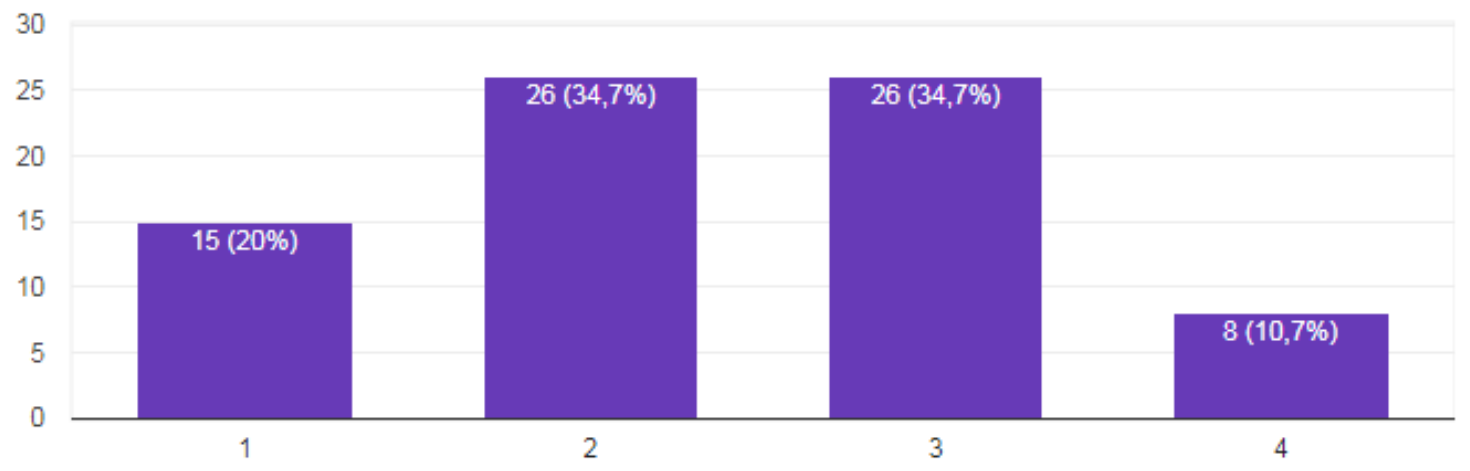

Gambar 12. Persentase Mata Kuliah Pendidikan Karakter Populer

Aspek keinginan untuk mendalami pendidikan karakter juga menjadi salah satu hal yang ditanyakan kepad mahasiswa. Hanya 6 orang mahasiswa atau 8\% saja yang sangat tidak setuju dengan pernyataan tersebut, kemudian 11 orang mahasiswa atau 14,7\% yang menyatakan tidak setuju. Ada 31 orang mahasiswa atau 41,3\% yang menyatakan setuju dengan pernyataan ingin mendalami pendidikan karakter, kemudian 27 orang mahasiswa atau 36\% yang menyatakan sangat setuju dengan pernyataan tersebut. Selegkapnya pada diagram berikut. 


\section{Saya ingin mendalami ilmu tentang pendidikan karakter}

\section{5 tanggapan}

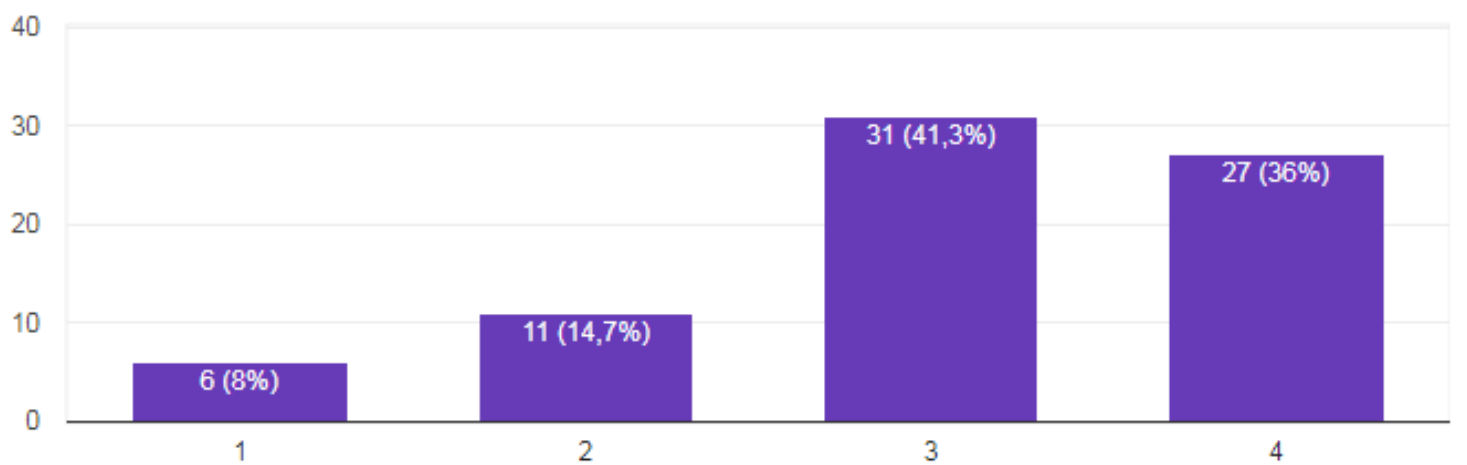

\section{Gambar 13. Persentase Keinginan Mendalami Pendidikan Karakter}

Terkait dengan pernyataak kesukaan terhadap mata kuliah pendidikan karakter dapat dijabarkan sebagai berikut. 6 orang mahasiswa atau setara dengan $8 \%$ menyatakan sangat tidak setuju serta tidak setuju dengan pernyataan tersebut, kemudian 29 orang atau 38,7\% menyatakan setuju dan sisanya atau 34 orang atau 45,3\% menyatakan sangat setuju dengan pernyataan tersebut. Selengkapnya pada diagram berikut.

\section{Saya menyukai mata kuliah yang berkaitan dengan pembentukan karakter \\ 75 tanggapan}

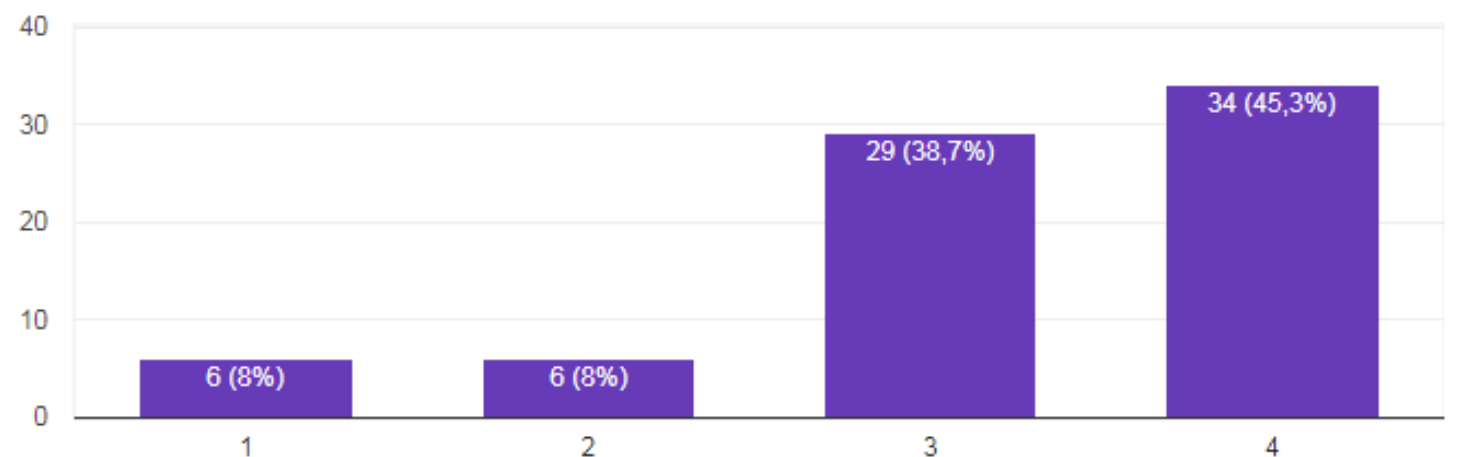

Gambar 14. Persentase Menyukai Pembentukan Karakter

Pernyataan berikutnya terkait dengan citra perguruan tinggi. Dalam pernyataan tentang banyaknya masyarakat yang berasal dari daerah yang sama dapat dijabarkan sebagai berikut. Mahasiswa memilih UIN Antasari menjadi pilihan kuliah dikarenakan banyaknya orang 
sedaerah yang berkuliah disana maka 9 orang atau $12 \%$ menyatakan sangat tidak setuju, kemudian 19 orang atau 25,3\% menyatakan tidak setuju bahwa faktor kedaerahan juga menjadi alasan dalam memilih perguruan tinggi. Menariknya ada 30 orang atau 40\% menyatakan bahwa mereka setuju bahwa kesamaan daerah menjadi alasan mereka dalam memilih kampus, dan 17 orang atau 22,7\% sangat setuju sekali dengan pernyataan tersebut.

\section{Citra Perguruan Tinggi}

\section{Sebagaian masyarakat di daerah saya pernah atau sedang kuliah di UIN Antasari Banjarmasin \\ 75 tanggapan}

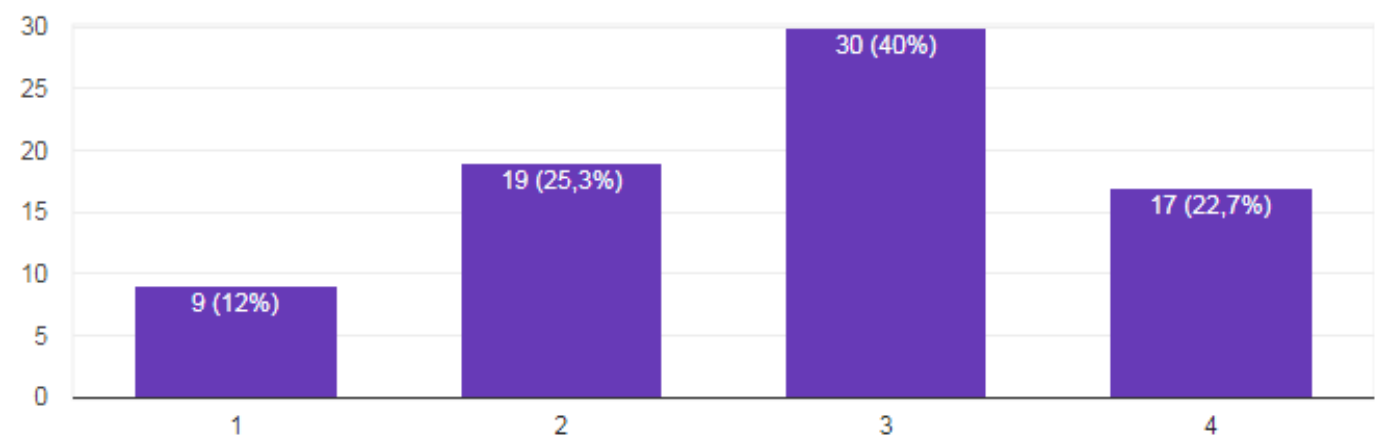

Gambar 15. Persentase Masyarakat Kuliah di UIN Antasari

Prospek pekerjaan di masa depan di dalam hasil angket didapati sebesar 6 mahasiswa atau $8 \%$ memilih sangat tidak setuju, 8 mahasiswa atau $10,7 \%$ memilih tidak setuju, paling dominan sebesar 33 mahasiswa atau 44\% memilih setuju, 28 mahasiswa atau 37,3\% memilih 
sangat setuju. Lebih lanjut pada diagram berikut:

\section{Prospek Pekerjaan di Masa Depan}

\section{Mata Kuliah Pendidikan Karakter mempunyai cakupan yang luas \\ 75 tanggapan}

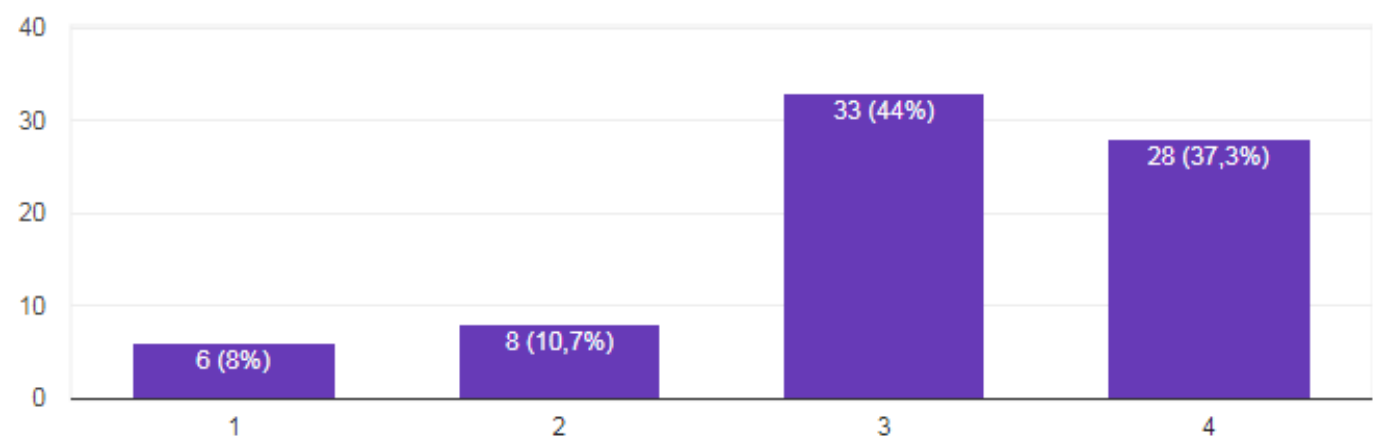

Gambar 16. Persentase Mata Kuliah Pendidikan Karakter Punya Cakupan Luas

Keyakinan setelah mempelajari mata kuliah pendidikan karakter dalam butir angket dengan pernyataan didapati hasil 4 mahasiswa atau 5,3\% memilih sangat tidak setuju, 21 mahasiswa atau 28\% memilih tidak setuju, 42 mahasiswa atau 56\% memilih setuju, dan 8 mahasiswa atau 10,7 memilih sangat setuju. Lebih lanjut pada diagram berikut:

Setelah mengikuti perkuliahan pendidikan karakter saya dapat bersaing

di dunia kerja

75 tanggapan

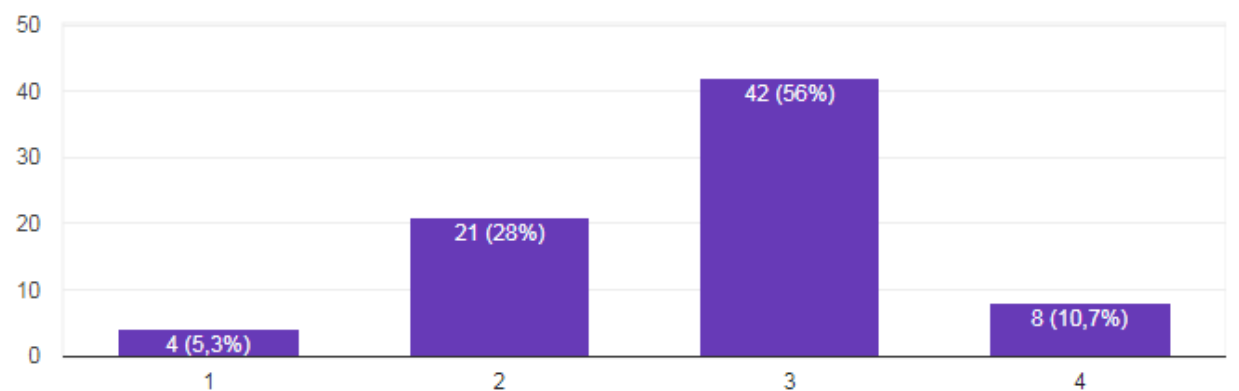

Gambar 17. Persentase Perkuliah Pendidikan dapat Bersaing di Dunia Kerja 
Selanjutnya menyangkut kemudahan diterima menjadi guru madrasah 6 orang atau $8 \%$ menyatakan tidak setuju dengan pernyataan tersebut, 8 orang atau 10,7\% menyatakan tidak setuju. Kemudian 41 orang atau setara dengan 54,7\% menyatakan setuju bahwa dengan mengambil mata kuliah pendidikan karakter dapat memudahkan ketika menjadi guru serta 20 orang atau setara $26,7 \%$ menyatakan sangat setuju dengan pernyataan terebut.

\section{Mudah diterima menjadi guru di Madrasah}

\section{5 tanggapan}

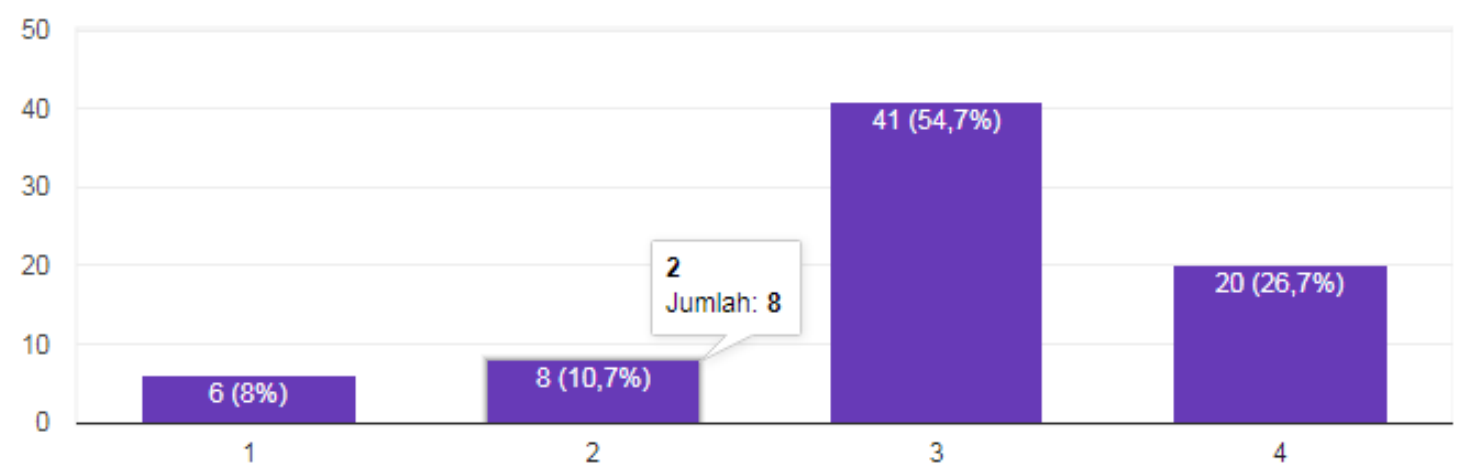

\section{Gambar 18. Persentase Mudah Diterima menjadi Guru di Madrasah}

Mengenai pernyataan tentang urgensi pendidikan karakter dapat tergambar pendapat mahasiswa tentang pentingnya pendidikan karakter. Hal tersebut dapat terlihat bahawa hanya 7 orang atau 9,3\% mahasiswa yang memilih pilihan bahwa di sangat tidak setuju bahwa pendidikan karakter sangat dibutuhkan, kemudian 5 orang atau 6,7\% menyatakan tidak setuju. Pada posisi yang setuju dapat terlihat bahwa 19 orang atau 25,3\% menyatakan Setuju dan mayoritas memilih sangat setuju sekali tentang urgensi atau pentingnya pendidikan karakter. jumlah yang memilih sangat setuju sekali adalah 44 orang atau 58,7\%. 
Selengkapnya pada diagram berikut.

\section{Pengetahuan tentang pendidikan karakter sangat dibutuhkan}

75 tanggapan

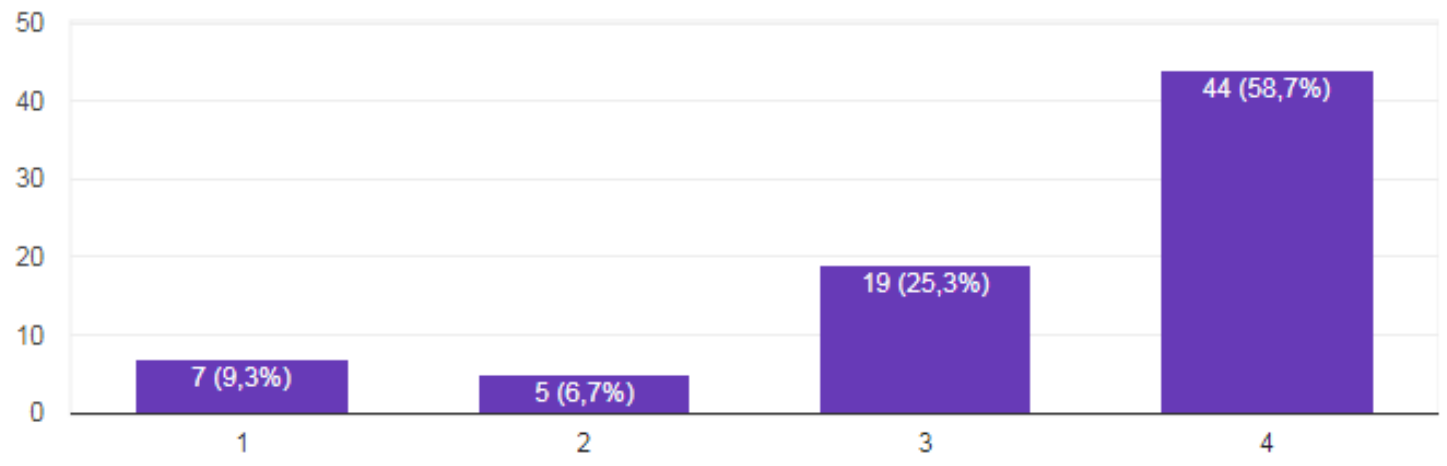

Gambar 19. Persentase Pengetahuan Pendidikan Karakter Dibutuhkan

\section{SIMPULAN}

Pada paparan hasil penelitian di atas dapat disimpulkan sebagai berikut:

1. Faktor-faktor yang mempengaruhi keputasan mahasiwa jurusan PGMI angkatan 2014 dalam memilih mata kuliah pilihan jurusan PGMI UIN Antasari Banjarmasin, antara lain orang tua, teman sebaya, gender, kepribadian (minat dan motivasi), citra perguruan tinggi, prospek pekerjaan.

2. Faktor yang paling dominan dalam mempengaruhi keputusan mahasiswa jurusan PGMI angkatan 2014 dalam memilih mata kuliah pilihan jurusan PGMI UIN Antasari Banjarmasin adalah faktor gender, faktor prospek pekerjaan serta, kepribadian. Dengan presentase 43 mahasiswa atau sebesar 57,3\% memilih bahwa pendidikan karakter untuk semua jenis kelamin. Presentasi prospek pekerjaan sebesar 42 mahasiswa atau 56\% memilih setuju bahwa pendidikan karakter bermanfaat untuk pekerjaan di masa depan.

\section{DAFTAR PUSTAKA}

Al-Suyuti, Jalaluddin. 1992. Jami'us Shogir. Surabaya: Dar-Al Nasyr Al Mishriyah. Aunillah, Nurla Isna. 2013. Panduan Menerapkan Pendidikan Karakter di Sekolah. Yogjakarta : Penerbit Laksana.

Andayani Dian dan Abdul Majid. 2011. Pendidikan Karakter Perspektif Islam. Bandung:

Remaja Rosdakarya. 
Arifin, Zainal. 1991. Evaluasi Intrusional. Bandung: PT. Remaja Rosdakarya 2011. Penelitian Pendidikan : Metode dan Paradigma Baru. Bandung: PT. Remaja Rosdakarya

Arikunto, Suharsimi. 2006. Prosedur Penelitian: Suatu pendekatan Praktik. Jakarta: Rineka Cipta (2013). Dasar-dasar Evaluasi Pendidikan. Jakarta: BumiAksara.

Daryanto, 2005. Evaluasi Pendidikan. Jakarta: PT Asdi Mahasatya

Hayati, Mimin. 2008. Model dan teknik penilaian pada tingkat satuan pendidikan, Jakarta: Gaung Persada Press.

Moleong, L.J. 2009. Cetakan ke-26. Metodologi Penelitian Kualitatif. Bandung : PT. Remaja Rosdakarya

Muhadjir, Noeng. 2002. Metodologi Penelitian Kualitatif Edisi IV. Yogyakarta: Rake Sarasin Purwanto. 2008. Metodologi Penelitian Kuantitatif untuk Psikologi dan Pendidikan. Yogyakarta: Pustaka Pelajar.

Rusdianto, (ed.).2012. Buku Panduan Internalisasi Pendidikan Karakter di Sekolah. Yogjakarta: DIVA Press.

Sudijono, Anas. 1996 . Pengantar Evaluasi Pendidikan. Jakarta: PT. Raja Grafindo Persada. Sanjaya, Wina. 2008. Perencanaan dan Desain Sistem Pembelajaran, Jakarta: Kencana. Soehartono, Irawan. 2002. Metode Penelitian Sosial. Bandung: PT. Remaja Rosda Karya. Suharsimi Arikunto dan Safruddin Abdul Jabar. 2004. Evaluasi Program Pendidikan. Jakarta: Bumi Aksara

Sugiyono. 2009. Memahami Penelitian Kualitatif. Bandung : CV. Alfabeta.

Sukmadinata, Nana Syaodih 2008. cet. Ke-4. Metode Penelitian Pendidikan. Bandung: PT. Remaja Rosdakarya

Toha, Chabib. (1996) Teknik Evaluasi Pendidikan. Jakarta: PT.Raja Grafindo Persada. Widoyoko, Eko Putro. (2011) Evaluasi Program Pembelajaran. Yoyakarta: Pustaka Pelajar Zubaedi. 2011. Desain Pendidikan Karakter. Jakarta: Kencana. 
AL-ADZKA, Jurnal Ilmiah Pendidikan Guru Madrasah Ib+idaiyah

Volume VIII, Nomor 02, Hal (85 - 106)

September 2018 